\title{
Evaluation of Root Noduletingrhizobial Strains for Fababean Crop at Kulumsa, Southeastern Highlands of Ethiopia
}

\author{
Almaz Admasu*, Kassu Tadesse and Anbesse Debebe \\ Kulumsa Agricultural Research Center, Ethiopian Institute of Agricultural Research, Kulumsa, Ethiopia \\ *Corresponding author: Almaz Admasu, Kulumsa Agricultural Research Center, Ethiopian Institute of Agricultural Research, Kulumsa, \\ Ethiopia \\ To Cite This Article: Almaz Admasu, Evaluation of Root Noduletingrhizobial Strains for Fababean Crop at Kulumsa, Southeastern Highlands \\ of Ethiopia. 2020 - 7(6). AJBSR.MS.ID.001214. DOI: 10.34297/AJBSR.2020.07.001214.
}

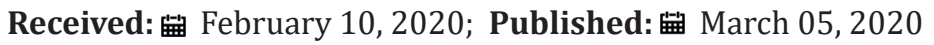

\begin{abstract}
The response of fababean to seed inoculation with ninestrains of Rhizobium leguminosarum along with recommended phosphorous from TSP fertilizer was examined in field experiments at a total of five sites from 2013 to 2015 at Kulumsa in the southeastern highlands of Ethiopia. Full (18$46 \mathrm{~kg} \mathrm{~N}-\mathrm{P} 205$ ha-1) and half doses nitrogen and phosphorous from inorganic source (DAP), and no input at all were also included in the treatments. The experiment was laid out in randomized complete block design with three replications. The result of 2013 trial showed seed inoculation with root noduleting rhizobium strains significantly improved the productivity of fababean. The highest grain yields of fababean were obtained from seed inoculations withstrainsEAL-110, FB-Murd, 1035 and 1018 along with recommended phosphorous from TSP.
\end{abstract}

Equivalent yields were also obtained from the applications of full and half doses of recommended nitrogen and phosphorous from DAP. Seed inoculation withstrainFB-140 and FB-9 along with recommended phosphorous from TSP also resulted in statistically similar biomass yields. Seed inoculations with strain FB-Murd, FB-140, FB-9 and FB-4 along with recommended phosphorous from TSP resulted in statistically the highest biomass yields in 2014. There were no significant yield and yield components responses of fababean to both seed inoculations with root noduleting rhizobium strains and applications of inorganic fertilizers in 2014 and 2015. Previous studies in Munesa district in the southeastern highlands of Ethiopia already confirmed that seed inoculations with strains EAL-110, 1018 and 1035 were efficient in fixing nitrogen. Promising results were obtained from inoculation of fababean seeds with strains FB-Murd, FB-140, FB-9 and FB-4.

Keywords: Fababean; Root noduleting rhizobium strains; Inorganic fertilizers; Seed inoculation; Yield; Yield components

\section{Introduction}

Fababean (Viciafaba) ranked first amongst cool season food legumes in terms of area of production. In 2014 / 2015 cropping season, 443,107 ha of land was allocated for fababean production, which was the first amongst pulse crops with a proportion of $28.4 \%$ (CSA, 2015). Apart from its contribution to cheap source of protein and foreign exchange earnings, it has also a great rolein sustainable soil fertility management due to its ability to fix atmospheric $\mathrm{N}_{2}[1,2]$.

Even though fababean is the leading pulse crop in the country, the national yield has remained low, which was $1.89 \mathrm{t} \mathrm{ha}^{-1}$ (CSA, 2015). Fababean production is constrained by a range of physical and biotic factors. Soil fertility depletion is one of the most import ant constraints limiting fababean production in the Ethiopian highlands [1].

Fababean seed inoculation with rhizobia is the cheapest and sustainable way to increase its nitrogen fixation potential. External seed inoculation is very important since there might be low population of effective indigenous rhizobia or higher competitions with non-effective ones [3]. Inoculation of fababean with rhizobium strains improves early nodulation and increases its yield [4]. In order to improve the production of fababean crop, application of chemical fertilizers, particularly nitrogen and phosphorus, are needed in addition to seed inoculation [5].Nitrogen is required as starter fertilizer at the early growth stage since there is no nodule formation, where atmospheric nitrogen is fixed [5]. Phosphorus 
deficiency is also another significant factor that reduces the nodulation since both effective rhizobium bacteria and the crop require in larger quantity [6]. The objective of this study was, therefore, to identify effective strains that increase production and productivity of fababean crop and enhance the soil fertility for subsequent cereal crops.

\section{Materials and Methods}

\section{Description of the Study Area}

This study was conducted at Kulumsa on-station and on the surrounding farmers' fields for three consecutive years. Kulumsa and its surrounding receive a mean annual rainfall of $811 \mathrm{~mm}$. The mean maximum and minimum temperatures of the area are $24.5^{\circ} \mathrm{C}$ and $10.5^{\circ} \mathrm{C}$, respectively. The soil of the area is characterized by verticluvisol with a clay loam soil texture.

\section{Experimental Set-up and Procedure}

The experiment included nine strains of Rhizobium leguminosarum (FB-4, FB-7, FB-9, FB-17, FB-140, FB-Murd, 1018, 1038 and EAL-110) along with full dose of recommended phosphorous (46 kg $\mathrm{P}_{2} \mathrm{O}_{5}$ ha $^{-1}$ ) from TSP fertilizer. Full (18-46 kg N- $\mathrm{P}_{2} \mathrm{O}_{5}$ ha $^{-1}$ ) and half $\left(9-23 \mathrm{~kg} \mathrm{~N}-\mathrm{P}_{2} \mathrm{O}_{5}\right.$ ha $\left.^{-1}\right)$ doses nitrogen and phosphorous from inorganic source (DAP), and no input at all were also included in the treatments. The experiment was laid out in randomized complete block design with three replications. Planting of trials were conducted during the fourth week of June in all years with fababean (Tumsa variety) at a seed rate of $150 \mathrm{~kg} \mathrm{ha}^{-1}$ at a total of seven sites. Seeds were drilled by hand at $0.40 \mathrm{~m}$ spacing between rows in plot sizes of $2.6 \mathrm{~m}$ by $4 \mathrm{~m}$. The spacing between plots and replications was $0.5 \mathrm{~m}$ and $1 \mathrm{~m}$, respectively. Based on the treatment set-up, fababean seeds were inoculated with respective strains and planted without contacting with the inorganic fertilizers. Strain EAL-110 was obtained from Menagesha Biotech Industry while the other eight strains from Holeta Agricultural Research Center. The phosphorus fertilizer was applied to soil according to the treatment arrangement as basal dose at planting in the form of triple super phosphate (TSP) and di-ammonium phosphate (DAP). Weeding was carried out by hand based on research recommendations. Pesticides, namely Macozeb and karate were applied against chocolate spot and aphids, respectively.

\section{Data Collection and Analysis}

The agronomic parameters collected (determined) were stand count, tillers per plant, plant height, spike per $\mathrm{m}^{-2}$, grain and aboveground total biomass yields, hectoliter and thousand kernel weights of fababean. When the crop was physiologically mature, harvesting was done from a net plot area of $4 \mathrm{~m}^{2}(2 \mathrm{~m}$ by $2 \mathrm{~m}$ ) by hand for yield determination. The harvested samples were subjected to air drying to constant moisture content, threshed manually, cleaned and the grain weight recorded. The weighed samples adjusted to $10 \%$ moisture content and converted into $\mathrm{kg} \mathrm{ha}^{-1}$ for statistical analysis. Two sites in the first year were dropped due to poor crop performance and five sites were considered for harvesting, data analysis and interpretation.

All yield and yield components data were combined across sites and subjected to analysis of variance using the general linear model procedure (Proc GLM) of SAS statistical package version 9.0 [7]. The significance of differences among treatment means was compared using Duncan multiple range test at the $5 \%$ level of probability.

\section{Results and Discussion}

The results of three years trials were inconsistent; hence, separate analysis of variances was conducted. The result of 2013 cropping season indicated that fababean yield and yield components were significantly affected by seed inoculation with root noduleting rhizobium strains and applications of inorganic fertilizers (Table 1). However, fababean crop did not respond to both seed inoculation with root noduleting rhizobium strains and applications of inorganic fertilizers in 2014 (except for harvest index and biomass yield) and 2015 cropping seasons (Table 2\&3).

Table 1: Significance of the effects of seed inoculation with root noduleting rhizobium strainsalong with inorganic fertilizers, location and their interaction on yield and yield components of fababean at Kulumsa in 2013.

\begin{tabular}{|c|c|c|c|c|c|c|c|c|}
\hline \multicolumn{9}{|c|}{ Yield and Yield Component Parameters } \\
\hline $\begin{array}{l}\text { Sources of vari- } \\
\text { ation }\end{array}$ & $\begin{array}{l}\text { Spike m }{ }^{2} \\
\quad \text { (No) }\end{array}$ & $\begin{array}{l}\text { Plant height } \\
\text { (cm) }\end{array}$ & $\begin{array}{c}\text { No of } \\
\text { seeds/ } \\
\text { plant }\end{array}$ & $\begin{array}{c}\text { Harvest } \\
\text { index (\%) }\end{array}$ & $\begin{array}{c}\text { Grain Yield } \\
\left(\mathrm{kg} \mathrm{ha}^{-1}\right)\end{array}$ & $\begin{array}{c}\text { Biomass yield } \\
\left(\mathrm{kg} \mathrm{ha}^{-1}\right)\end{array}$ & $\begin{array}{c}\text { Hecto liter } \\
\text { weight (kg } \\
\left.\text { hl }^{-1}\right)\end{array}$ & $\begin{array}{c}\text { Thousand } \\
\text { kernel weight } \\
\text { (gm) }\end{array}$ \\
\hline Replication & ns & ns & ns & ns & $* *$ & $* *$ & ns & ns \\
\hline Treatment (Trt) & ns & ns & $*$ & ns & $*$ & $*$ & ns & ns \\
\hline Mean & 40 & 139.7 & 31 & 30.3 & 4480.54 & 151.95 & 70.93 & 871.04 \\
\hline $\mathrm{CV}$ & 15.18 & 5.8 & 17.65 & 16.32 & 8.55 & 15.38 & 1.1 & 3.84 \\
\hline
\end{tabular}

Table 2: Significance of the effects of seed inoculation with root noduleting rhizobium strainsalong with inorganic fertilizers, location and their interaction on yield and yield components of fababean at Kulumsa in 2014.

\begin{tabular}{|c|c|c|c|c|c|c|c|c|}
\hline \multicolumn{9}{|c|}{ Yield and Yield Component Parameters } \\
\hline $\begin{array}{l}\text { Sources of } \\
\text { variation }\end{array}$ & $\begin{array}{l}\text { Spike m}^{2} \\
\text { (No) }\end{array}$ & $\begin{array}{l}\text { Plant height } \\
\text { (cm) }\end{array}$ & $\begin{array}{c}\text { No of seeds } \\
\text { / plant }\end{array}$ & $\begin{array}{c}\text { Harvest } \\
\text { index }(\%)\end{array}$ & $\begin{array}{l}\text { Grain Yield } \\
\left(\mathrm{kg} \mathrm{ha}^{-1}\right)\end{array}$ & $\begin{array}{c}\text { Biomass yield } \\
\left(\mathrm{kg} \mathrm{ha}^{-1}\right)\end{array}$ & $\begin{array}{c}\text { Hecto liter } \\
\text { weight }\left(\mathrm{kg} \mathrm{hl}^{-1}\right)\end{array}$ & $\begin{array}{c}\text { Thousand kernel } \\
\text { weight (gm) }\end{array}$ \\
\hline Replication & ns & ns & ns & ns & $* *$ & $* *$ & ns & * \\
\hline
\end{tabular}




\begin{tabular}{|c|c|c|c|c|c|c|c|c|}
\hline Location (Loc) & $* *$ & ns & $* * *$ & $* * *$ & $* *$ & $* * *$ & ns & ns \\
\hline Treatment (Trt) & ns & ns & ns & $* * *$ & ns & $* *$ & ns & ns \\
\hline Loc*Trt & ns & ns & ns & * & ns & $*$ & ns & ns \\
\hline Mean & 45 & 6.67 & 22 & 31.18 & 3885.9 & 12992.36 & 72.59 & 703.75 \\
\hline $\mathrm{CV}$ & 8.62 & 0.2 & 12.38 & 13.78 & 16.12 & 19.24 & 0.92 & 3.53 \\
\hline
\end{tabular}

Table 3: Significance of the effects of seed inoculation with root noduleting rhizobium strainsalong with inorganic fertilizers, location and their interaction on yield and yield components of fababean at Kulumsa in 2015.

\begin{tabular}{|c|c|c|c|c|c|c|c|}
\hline \multicolumn{8}{|c|}{ Yield and Yield Component Parameters } \\
\hline Sources of variation & $\begin{array}{c}\text { Plant } \\
\text { height }(\mathrm{cm})\end{array}$ & $\begin{array}{l}\text { Spike m² } \\
\text { (No) }\end{array}$ & No of seeds/plant & $\begin{array}{c}\text { Harvest } \\
\text { index (\%) }\end{array}$ & $\begin{array}{l}\text { Grain Yield } \\
\left(\mathrm{kg} \mathrm{ha}^{-1}\right)\end{array}$ & $\begin{array}{c}\text { Biomass yield } \\
\left(\mathrm{kg} \mathrm{ha}^{-1}\right)\end{array}$ & $\begin{array}{c}\text { Thousand kernel } \\
\text { weight (gm) }\end{array}$ \\
\hline Replication & ns & $* *$ & $* *$ & * & ns & $* *$ & * \\
\hline Location (Loc) & ** & $* * *$ & $* * *$ & * & $* * *$ & $* * *$ & $* * *$ \\
\hline Treatment (Trt) & ns & ns & ns & ns & ns & ns & ns \\
\hline Loc*Trt & ns & ns & ns & ns & ns & ns & ns \\
\hline Mean & 130 & 51 & 29 & 32.04 & 3404.3 & 11033.1 & 632 \\
\hline $\mathrm{CV}$ & 6.32 & 9.43 & 26.46 & 24.47 & 15.01 & 29.27 & 6.84 \\
\hline
\end{tabular}

\begin{tabular}{|c|c|c|}
\hline Treatments & Grain yield $\left(\mathrm{kg} \mathrm{ha}^{-1}\right)$ & Biomass yield ( $\mathrm{kg} \mathrm{ha}^{-1}$ ) \\
\hline No input (control) & $4379.6^{\mathrm{bcd}}$ & $12830^{\mathrm{b}}$ \\
\hline Recommended rate of fertilizer (100 kg TSP ha ${ }^{-1}$ ) & $4865.7^{\mathrm{ab}}$ & $16309^{\mathrm{ab}}$ \\
\hline $1 / 2 \mathrm{RR}$ rate of fertilizer ( $\left.50 \mathrm{~kg}^{\mathrm{TSP}} \mathrm{ha}^{-1}\right)$ & $4554.8^{\mathrm{abcd}}$ & $14317^{\mathrm{b}}$ \\
\hline FB-4 + 100 kg TSP ha-1 & $4339.9^{\mathrm{bcd}}$ & $14308^{\mathrm{b}}$ \\
\hline FB-7 + $100 \mathrm{~kg} \mathrm{TSP} \mathrm{ha}^{-1}$ & $4034.8^{\mathrm{cd}}$ & $14236^{\mathrm{b}}$ \\
\hline FB-9 + $100 \mathrm{~kg}$ TSP ha ${ }^{-1}$ & $4360.5^{\mathrm{bcd}}$ & $15646^{\mathrm{ab}}$ \\
\hline FB-17 + 100 kg TSP ha-1 & $3875.1^{\mathrm{d}}$ & $12452^{\mathrm{b}}$ \\
\hline FB-140 + 100 kg TSP ha-1 & $4291.2^{\mathrm{bcd}}$ & $15811^{\mathrm{ab}}$ \\
\hline FB-Murd + 100 kg TSP ha ${ }^{-1}$ & $4737.7^{\mathrm{abc}}$ & $16419^{\mathrm{ab}}$ \\
\hline 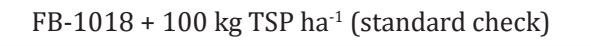 & $4523.3^{\mathrm{abcd}}$ & $15713^{\mathrm{ab}}$ \\
\hline 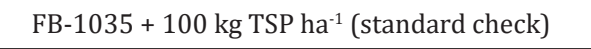 & $4594.8^{\mathrm{abcd}}$ & $14259^{b}$ \\
\hline EAL-110 + $100 \mathrm{~kg} \mathrm{TSP} \mathrm{ha}^{-1}$ (standard check) & $5208.9^{a}$ & $19702^{\mathrm{a}}$ \\
\hline
\end{tabular}

The result of the 2013 trial showed that seed inoculation with root noduleting rhizobium strains improved the yields of fababean (Table 4). The highest grain yield of fababean (5209 kg ha-1) was obtained from seed inoculation with strain EAL-110 along with application of full dose of recommended phosphorous fertilizer (46 kg $\mathrm{P}_{2} \mathrm{O}_{5}$ ha $^{-1}$ ) from TSP. However, statistically similar grain yields of fababean were obtained from the applications of full dose of recommended nitrogen and phosphorous (18-46 kg N- $\mathrm{P}_{2} \mathrm{O}_{5} \mathrm{ha}^{-1}$ ) from DAP, seed inoculation with strain FB-Murd along with recommended phosphorous from TSP, seed inoculation with strain 1035 along with recommended phosphorous from TSP, half dose of recommended nitrogen and phosphorous (9-23 kg N-P205 ha-1)from DAP, and seed inoculation with strain 1018 along with recommended phosphorous from TSP.
The highest biomass yield (19702kg ha-1) was also recorded from seed inoculation with strain EAL-110 along with recommended phosphorous fertilizer from TSP. However, this result was also statistically similar with seed inoculation with strain FB-Murd along with recommended phosphorous from TSP, full dose of recommended nitrogen and phosphorous from DAP, seed inoculation with strainFB-140 along with recommended phosphorous from TSP, seed inoculation with strain 1018 along with recommended phosphorous from TSP, and seed inoculation with strain FB-9 along with recommended phosphorous from TSP.

Except for harvest index and biological yield in 2014, no significant yield and yield components responses were obtained due to both seed inoculation with root noduleting rhizobium strains and applications of inorganic fertilizers during 2014 and 2015 crop- 
ping seasons (Table 5). The non-significant yield responses might be attributed to the relatively high soil fertility status of the experimental sites. The highest grain yields of fababean from plots which did not receive any fertilizer implied the highest soil fertility status of the testing sites. Besides, there were very high and low rainfall conditions in 2014 and 2015 cropping seasons, respectively (Fig- ure 1). The total monthly rainfall in 2014 and 2015 were above and below the 36 years average, respectively for most of the fababean crop growing period (June to October). These might be attributed to the leaching of nutrients through excess soil moisture and insolubility of nutrients due to shortage of soil moisture in 2014 and 2015, respectively.

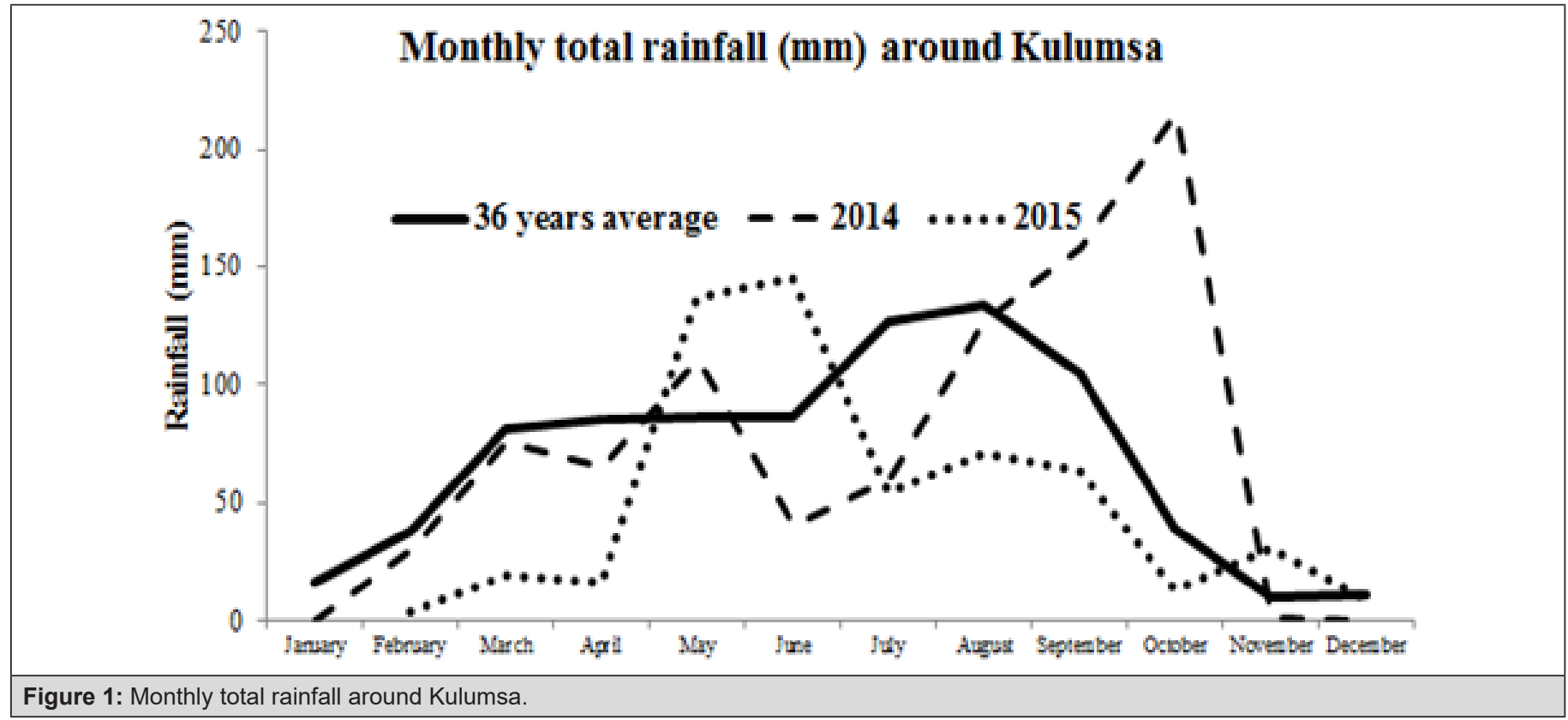

\begin{tabular}{|c|c|c|c|c|}
\hline \multirow{2}{*}{ Treatments } & \multicolumn{2}{|c|}{2014} & \multicolumn{2}{|c|}{2015} \\
\hline & Grain yield (kg ha-1) & Biomass yield (kg ha-1) & Grain yield (kg ha-1) & Biomass yield $\left(\mathrm{kg} \mathrm{ha}^{-1}\right)$ \\
\hline No input (control) & 4390.8 & $12838^{\mathrm{bc}}$ & 3268.8 & 8858 \\
\hline $\begin{array}{l}\text { Recommended rate of fertilizer } \\
\qquad\left(100 \mathrm{~kg} \mathrm{TSP} \mathrm{ha}^{-1}\right)\end{array}$ & 3596 & $13722^{\mathrm{abc}}$ & 3489.1 & 10866 \\
\hline $\begin{array}{l}1 / 2 \mathrm{RR} \text { rate of fertilizer (50 kg } \\
\text { TSP ha }{ }^{-1} \text { ) }\end{array}$ & 3634.7 & $11897^{\mathrm{bc}}$ & 3688.3 & 11158 \\
\hline FB-4 + 100 kg TSP ha ${ }^{-1}$ & 3710.6 & $13751^{\mathrm{abc}}$ & 3465.6 & 11054 \\
\hline FB-7 + 100 kg TSP ha ${ }^{-1}$ & 3843.5 & $11721^{\mathrm{bc}}$ & 3272.4 & 10770 \\
\hline FB-9 + 100 kg TSP ha-11 & 3480 & $14567^{\mathrm{ab}}$ & 3505.9 & 12031 \\
\hline FB-17 + 100 kg TSP ha-1 & 3828.2 & $12458^{\mathrm{bc}}$ & 3469.9 & 10343 \\
\hline FB-140 + $100 \mathrm{~kg}^{\mathrm{TSP}} \mathrm{ha}^{-1}$ & 4039.5 & $16747^{\mathrm{a}}$ & 3390.3 & 12455 \\
\hline FB-Murd + 100 kg TSP ha-1 & 3910.7 & $11739^{\mathrm{bc}}$ & 3370.4 & 11632 \\
\hline $\begin{array}{l}\text { FB-1018 + } 100 \text { kg TSP ha-1 } \\
\text { (standard check) }\end{array}$ & 4307.2 & $14017^{\mathrm{ab}}$ & 3369 & 10734 \\
\hline $\begin{array}{l}\text { FB-1035 + } 100 \text { kg TSP ha-1 } \\
\text { (standard check) }\end{array}$ & 3761.1 & $10541^{\mathrm{c}}$ & 3320.2 & 10569 \\
\hline $\begin{array}{l}\text { EAL-110 + } 100 \text { kg TSP ha-1 } \\
\text { (standard check) }\end{array}$ & 4128.5 & $11910^{\mathrm{bc}}$ & 3242.1 & 11926 \\
\hline
\end{tabular}

However, there was significant response for biomass yield of fababean due to seed inoculation with strains and application of inorganic fertilizers. The highest biomass yield (16747 $\mathrm{kg} \mathrm{ha}^{-1}$ ) was obtained from seed inoculation with strainFB-140 along with recommended phosphorous fertilizer from TSP. However, this result was statistically similar with seed inoculation with strainFB-9 along with recommended phosphorous fertilizer from TSP, seed inoculation with strain FB-4 along with recommended phosphorous 
fertilizer from TSP, and recommended nitrogen and phosphorous from DAP.

\section{Conclusion}

The 2013 result indicated that seed inoculation with root noduleting rhizobium strainsalong with application of full dose of phosphorous from TSP fertilizer improved the productivity of fababean at Kulumsa. The highest grainand biomass yieldsof fababean were obtained from seed inoculation with strain EAL-110 along with full dose of recommended phosphorous from TSP. However, the grain yield result was statistically similar with the application of full dose of recommended nitrogen and phosphorous from DAP, seed inoculation with strain FB-Murd along with recommended phosphorous from TSP, seed inoculation with strain 1035 along with recommended phosphorous from TSP, half dose of recommended nitrogen and phosphorous from DAP, and seed inoculation with strain1018 along with recommended phosphorous from TSP. In addition to these strains, seed inoculation with strainFB-140 and FB-9 along with recommended phosphorous from TSP resulted in statistically similar biomass yields.

The results of the 2014 and 2015 trials showed no significant responses to both seed inoculation with root noduleting rhizobium strains and application of inorganic fertilizers at Kulumsa [8,9]. The non-significant response might be attributed to the extremely high and low rainfall conditions at critical crop development stages in 2014 and 2015 cropping seasons, respectively. Regardless of these extreme weather conditions, seed inoculation with strains FB-Murd, FB-140, FB-9 and FB-4 along with application of full dose of recommended phosphorous from TSP resulted in statistically the highest biomass yield in 2014 .

Previous studies conducted at Munesa district in the southeastern highlands of Ethiopia already confirmed that seed inoculation with strains EAL-110, 1018 and 1035 along with application of full dose of recommended phosphorous from TSP were effective in fixing of nitrogen with fababean crop [10]. The result of 2013 and the implication from 2014 showed that FB-Murd along with applica- tion of full dose of recommended phosphorous from TSP was promising. In order to make the final conclusion, seed inoculation with strainsFB-9 and FB-4 need to be studied further under different soil types and agroecologies. It is recommended to check the viability of strains just prior to planting.

\section{References}

1. Getachew Agegnehu, Berhane Lakew, Paul N Nelson (2014) Cropping sequence and nitrogen fertilizer effects on the productivity and quality of malting barley and soil fertility in the Ethiopian highlands. Archives of Agronomy and Soil Science 60(9): 1261-1275.

2. Amanuel Gorfu, Kefyalew Girma, DG Tanner, Asefa Taa, Shambel Maru, et al. (2000) Effect of Crop Rotation and Fertilizer Application on Wheat Yield Performance across Five Years at Two Locations in Southeastern Ethiopia. In: The Eleventh Regional Wheat Workshop for Eastern, Central and Southern Africa Pp. 264-274.

3. Tolera A, Daba F, Zerihun A (2009) A review of organic and Biological Soil Fertility Management integrated with NP on Crops Yield and Soil Fertility Improvement in High and Mid Altitude Areas of Western oromiya, Ethiopia. Improved natural Resource management Technologies for Food Security, Poverty Reduction and Sustainable Development. Ethiopian Society of Soil Science.

4. Carter JM, Gardner WK, Gibson AH (1994) Improved growth and yield of faba bean (Viciafabaecv Fiord) by inoculation with strains of rhizobium leguminosarumbiovar. viciae in acid soils in South West Victoria. Austerlian Journal of Agricultural Research 45(3): 613-623.

5. Otieno PE, Muthomi JW, Cheminingwa GN, Nderitu JH (2009) Effect of rhizobia inoculation, farm yard manure and nitrogen fertilizer on nodulation and yield of food grain legumes. J Biol Sci 9(4): 326-332.

6. Getachew A, Rezene F (2006) Response of Faba Bean to Phosphate Fertilizer and Weed Control on Nitisols of Ethiopian Highlands. Italian journal of Agronomy 1(2).

7. (2008) SAS Institute SAS/STAT Software Version 9.2. SAS Institute, USA.

8. aftom Zebib, Geremew Bultosa, Solomon Abera (2014) Report on Area and production of major crops for 2013 / 2014 (private Peasant Holdings, Meher Season). Statistical Bulletin No. 532, Ethiopia.

9. O Hara GM, Bookered N, Dilworth MJ (1988) Mineral constraints to nitrogen fixation. Plant and soil 108: 93-110.

10. Sorwli JI, Bradford LR (1986) The nitrogen fixing potential of viciafaba rhizobia (R. leguminosarum) from different agricultural locations. Plant and soil 92: 249-254. 